\title{
ANALISIS CURAH HUJAN PENYEBAB BANJIR BESAR DI JAKARTA PADA AWAL FEBRUARI 2007
}

\author{
Oleh: \\ Sutopo Purwo Nugroho
}

\author{
Peneliti di Pusat Teknologi Pengelolaan Lahan, Wilayah dan Mitigasi Bencana BPPT
}

\begin{abstract}
Flood that has occured in Jakarta in 27 January - 2 February 2002 was a result of heavy rain and impact of over discharge streams within its catchment area. Furthermore, occurence of low air pressure around northern Australia and Intertropical Convergence Zone (ITCZ) around Java Sea up to Banda Sea, has driven moists in the Asia into the area. Precipitation resulting flood is a return period about 1 to 1000. In Ciliwung watershed, mean rainfall of $142,5 \mathrm{~mm} /$ day and return period of about 100 years. This was bigger than mean rainfall during the period of 29 January 2002 about $110 \mathrm{~mm} /$ day that return period 200 years.
\end{abstract}

Katakunci : hujan, banjir, periode ulang.

\section{PENDAHULUAN}

Setiap tahun bencana banjir besar banyak terjadi di daerah dataran rendah di Asia (FAO \& CIFOR, 2005). Demikian pula halnya dengan bencana banjir di Indonesia. Meningkatnya kejadian bencana alam yang terjadi di dunia merupakan salah satu indikator dari pembangunan yang tidak berkelanjutan (Chan et al., 1996; United Nations, 1994; Burton, 1993). Bencana lingkungan dalam pembangunan merupakan masalah penting yang belum dapat dipecahkan dan pengurangan bencana tersebut menjadi dimensi yang penting dari pembangunan berkelanjutan.

Dari sekian banyak bencana alam, bencana banjir merupakan bencana dengan mempunyai frekuensi yang paling besar dan menimbulkan kerugian yang besar pula (Gupta, 2003; Parry et al., 1992). Masalah banjir hingga saat ini belum dapat diselesaikan secara tuntas, bahkan masalah tersebut justru mengindikasikan semakin meningkat, baik intensitas, frekuensi maupun sebarannya.

Demikian pula halnya dengan bencana di Indonesia. Banjir merupakan salah satu jenis bencana hidrometeorologi yang paling sering terjadi. Frekuensi kejadian banjir semakin meningkat dari tahun ke tahun, bahkan intensitas dan sebarannya pun juga semakin meningkat. Selain dipengaruhi oleh perubahan iklim global, khususnya curah hujan, juga dipengaruhi oleh adanya perubahan penggunaan lahan, pemanfaatan bantaran sungai untuk permukiman dan industri, kerusakan DAS dan sebagainya.

Kondisi demikian banyak terjadi di kotakota besar di Indonesia, dimana sebagian besar kota berkembang di dataran banjir dan dataran rendah, seperti Jakarta, Semarang, Surabaya,
Medan, Makassar dan sebagainya. Banjir di Jakarta merupakan banjir yang rutin. Artinya setiap musim penghujan banjir selalu terjadi di daerah tersebut. Sejarah mencatat bahwa bencana banjir besar yang pernah terjadi di Jakarta adalah pada tahun 1621, 1654, 1918, 1942, 1976, 1996, 2002, dan 2007.

Perbedaan antara banjir-banjir yang pernah terjadi selama tahun-tahun tersebut adalah dimensi penyebab dan akibat banjir tersebut. Pada periode sebelum tahun 1970-an, penyebab utama adalah faktor alam. Sesudah periode tersebut penyebab banjir menjadi semakin kompleks, bukan hanya faktor alam, tetapi faktor sosial ekonomi dan budaya serta akibat yang ditimbulkannya juga berbeda.

Dimensi banjir menjadi lebih besar akibat adanya perkembangan kawasan yang tidak tidak didukung dengan teknologi pengendalian banjir yang memadai. Hal ini terlihat dari rendahnya kemampuan drainase mengeringkan kawasan terbangun dan rendahnya kapasitas seluruh prasarana pengendali banjir, seperti sungai, poulder, pintu pengatur, bendung, dan sebagainya. Selain itu secara geomorfologis Jakarta terletak pada dataran banjir dimana terdapat 13 sungai, yaitu : Sungai Cakung, Jatikramat, Buaran, Sunter, Cipinang, Ciliwung, Cideng, Krukut, Grogol, Sekretaris, Pesanggrahan, Angke dan Mookervart. Rata-rata curah hujan tahunan yang cukup tinggi yaitu 2000 - $3000 \mathrm{~mm}$ dan daerah pengaruh pasang surut laut mencapai 40\% (24.000 ha) dari luas keseluruhan 64.000 ha, maka masalah banjir bukan menjadi fenomena yang aneh.

Banjir di Jakarta selalu menimbulkan kerugian. Banjir besar pada periode Februari 2007 menyebabkan 79 orang meninggal dunia, 1 orang hilang, dan 2.349 orang pengungsi di 
DKI Jakarta, 106.406 pengungsi di Provinsi Jawa Barat, serta 52 orang pengungsi di Provinsi BantenUntuk banjir besar pada periode Februari 2007, nilai kerusakan dan kerugian terhadap aset yang terkena banjir, baik aset milik pemerintah, aset dunia usaha dan aset masyarakat diperkirakan senilai $\mathrm{Rp}$ 5,16 triliun.

Selain itu, berdasarkan perkiraan yang dilakukan oleh APINDO dan penilaian yang dilakukan Asosiasi Asuransi Umum Indonesia (AAUI), diperkirakan kerugian ekonomi yang harus ditanggung selama sekitar 1 (satu) minggu kejadian bencana banjir di wilayah Jabodetabek sebesar US $\$ 400$ juta (sekitar Rp 3,6 triliun), yang mencakup kerugian dan kerusakan yang dialami perumahan, kendaraan bermotor, bangunan industri dan fasilitas perdagangan. Nilai ini tidak hanya karena kerusakan aset fisik akan tetapi juga karena 'opportunity loss' atau hilang nya peluang karena aktivitas, terutama kegiatan ekonomi, yang tidak dapat dilakukan akibat banjir. Nilai perkiraan sebesar US $\$ 400$ juta (Bappenas, 2007).

Timbulnya banjir besar tersebut tentu saja disebabkan oleh curah hujan dan berbagai faktor pemicu lainnya. Mengapa di Jakarta terjadi banjir tersebut dengan ekskalasi yang demikian besar? Pertanyaan ini seringkali dikemukakan oleh banyak pihak. Banyak pihak yang telah mengemukakan faktor-faktor penyebabnya. Namun umumnya masih bersifat kualitatif dan umum. Oleh karena itu dalam penelitian ini dibahas mengenai faktor-faktor penyebabnya, khususnya curah hujan dan aliran permukaannya sehingga dapat memberikan gambaran secara lebih jelas.

\section{METODE PENELITIAN}

Untuk mengetahui faktor-faktor penyebab banjir maka dilakukan analisis meteorologi dengan mengkaji citra satelit cuaca, SST dan streamline pada saat kejadian. Data curah hujan dianalisis dengan membandingkan dengan analisis frekuensi hujan maksimum untuk daerah Jakarta dan sekitarnya. Analisis frekuensi hujan maksimum tersebut mengacu pada hasil penelitian JICA dan Direktorat Jenderal Pengairan (JICA, 1997). Dalam analisis frekuensi data curah hujan maksimum tersebut dilakukan dengan metode Gumbel.

Pemilihan distribusi frekuensi Gumbel ini didasarkan hasil pengujian kecocokan (testing of goodness of fit) dengan uji Chi-kuadrat dan uji Smirnov-Kolmogorov. Metode Gumbel mendasarkan atas karakteristik dari pemencaran dengan menggunakan suatu koreksi yang variabel. Angka koreksi Gumbel merupakan suatu fungsi dari nomor urut relatif dalam serinya $(\mathrm{m}: \mathrm{N})$ dan sifat pemencarannya (Subarkah, 1980).

Persamaan yang digunakan untuk menghitung periode ulang $(\mathrm{T})$ adalah :

$$
T=\frac{1}{m+c-1}
$$

dimana :

$$
\begin{aligned}
& \mathrm{T}=\text { periode ulang } \\
& \mathrm{m}=\text { nomor urut data dimulai dari yang }
\end{aligned}
$$

Berhubung data curah hujan yang digunakan merupakan harga-harga maksimum dari banyak seri, maka probabilitas $(P)$ timbulnya suatu harga sama dengan atau kurang dari $\mathrm{X}$ ditentukan oleh persamaan :

$$
P=e^{-e^{-y}}
$$

dimana :

$$
\begin{aligned}
\mathrm{y}= & \text { variabel tanpa dimensi }=\mathrm{a}(\mathrm{X}-\mathrm{Xf}), \\
& \text { dengan } a=\frac{1,2825}{\sigma_{x}} \\
\mathrm{Xf}= & \text { modus, yang diperoleh dari } \mathrm{Xf}=\mathrm{x}-0,45 \\
& \begin{array}{l}
\sigma_{\mathrm{x}} \\
\sigma_{\mathrm{x}}=
\end{array} \\
\mathrm{x} \quad \begin{array}{l}
\text { penyimpangan standar terhadap harga } \\
\text { ratana }
\end{array} & \text { harga rata-rata dari } \mathrm{X}
\end{aligned}
$$

Analisis hujan secara keruangan dilakukan dengan membuat peta isohyet, yaitu garis yang menghubungkan titik-titik yang mempunyai curah hujan yang sama.

\section{HASIL DAN PEMBAHASAN}

Banjir besar pada periode akhir Januari hingga awal Februari 2007 disebabkan oleh tingginya curah hujan pada saat ini.. Hujan yang turun semenjak tanggal 29 Januari hingga 2 Februari 2007 adalah awal dari bencana banjir yang melanda Jakarta dan sekitarnya. Berdasarkan pengamatan data meteorologi maka tingginya curah hujan disebabkan oleh :

a) Adanya daerah dengan tekanan udara rendah di Australia bagian utara dan adanya daerah pertemuan angin (ITCZ) 
pada posisi di sekitar laut Jawa hingga Laut Banda; (Gambar 1);

b) Naiknya suhu muka laut sepanjang ITCZ meningkatkan pertumbuhan awan hujan

c) Adanya kenaikan suhu permukaan laut sebesar $0,5^{0}-1,0^{\circ} \mathrm{C}$ di wilayah perairan Indonesia, yang mengakibatkan naiknya potensi pembentukan awan hujan di wilayah Indonesia

d) Februari $2007 \mathrm{El}$ Nino lemah masih berlangsung, MJO sedang melintasi Indonesia, sebagian besar wilayah Indonesia tertutup awan dan mengalami hujan lebat, Jakarta banjir sejak 2 Februari 2007 dan meluas selama beberapa hari. Waktunya bersamaan dengan bulan purnama sehingga pasang laut naik.

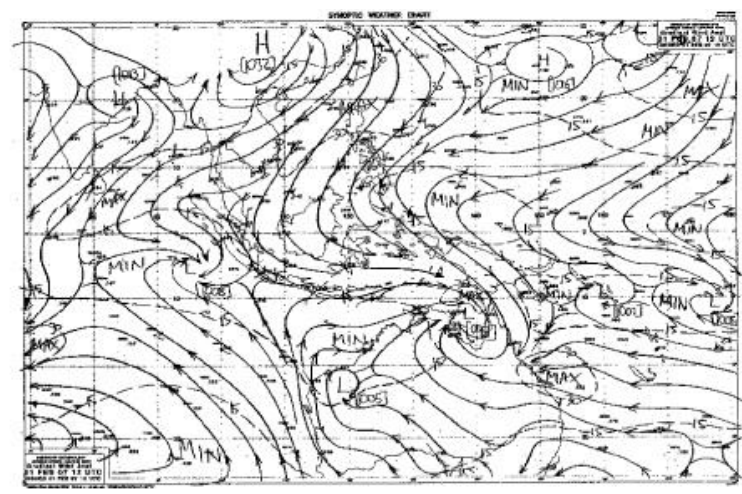

Gambar 1. Streamline Pada Tanggal 1 Februari 2007 jam 12.00 UTC/19.00 WIB

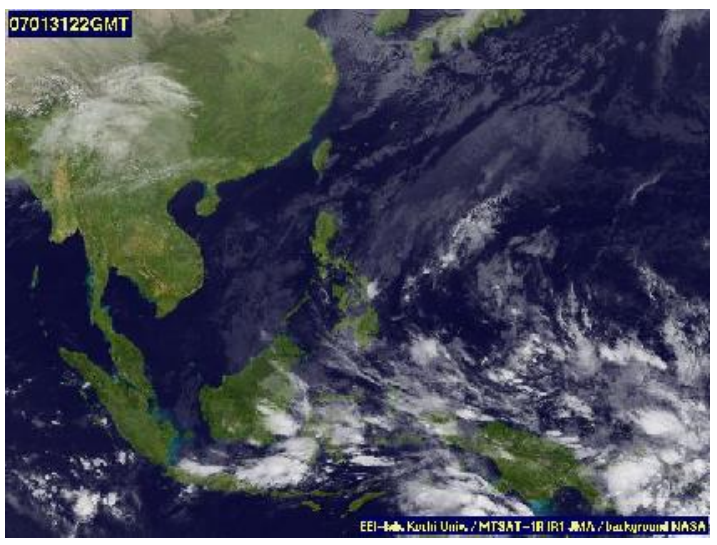

Gambar 2. Citra Satelit Yang Menunjukkan Tutupan Awan Pada 1 Februari 2007 jam 06.00 WIB

Berdasarkan pengamatan hujan oleh Badan Meteorologi dan Geofisika (BMG), curah hujan pada 2 Februari 2007, curah hujan terbesar terjadi di Ciledug yaitu 339,8 mm/hari. Di wilayah Jakarta curah hujan merata dengan tebal hujan yang tinggi. Tercatat di Kemayoran sebesar $235 \mathrm{~mm} /$ hari, Pasar Minggu 220 $\mathrm{mm}$ /hari, Pakubuwono $178 \mathrm{~mm} /$ hari dan Tanjung
Priok $168 \mathrm{~mm} /$ hari. Konsentrasi curah hujan terjadi disekitar Ciledug, sedangkan di daerah Bogor hingga Puncak curah hujan yang terjadi cukup kecil (Gambar 3).

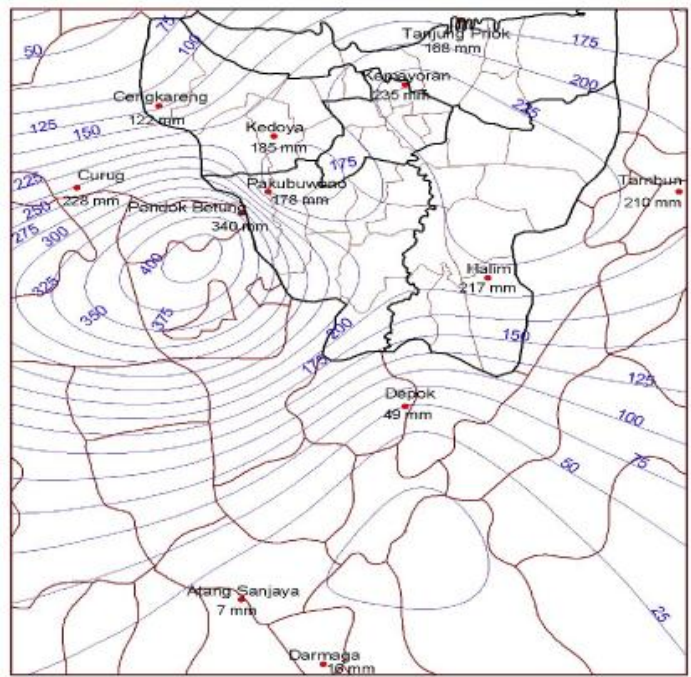

Gambar 3. Isohyet Curah Hujan Daerah Jakarta Dan Sekitarnya Pada 2 Februari 2007

Jika dibandingkan dengan kejadian banjir pada 29 Januari 2002, dimana Jakarta dan sekitarnya juga terjadi banjir besar maka terdapat perbedaan dalam tebal dan sebaran hujan. Puncak kejadian hujan terjadi pada tanggal 29 Januari 2002, dimana rata-rata curah hujan untuk daerah Jabotabek mencapai 120 mm. Curah hujan yang terjadi pada waktu itu di Bekasi tercatat $250 \mathrm{~mm}$, Tanjung Priok sebesar $147 \mathrm{~mm}$, Jakarta Pusat (BMG) dan Halim Perdana Kusumah sebesar 104 mm, Depok sebesar 149 $\mathrm{mm}$, Tambun sebesar $168 \mathrm{~mm}$, dan Bogor hingga Gunung Mas mencapai 147 mm. (Tabel 1).

Tabel 1. Perbandingan Curah Hujan Saat Banjir Besar Di Jakarta

\begin{tabular}{|l|l|c|c|}
\hline \multirow{2}{*}{ No } & \multirow{2}{*}{ Stasiun Hujan } & \multicolumn{2}{|c|}{ Tebal Hujan (mm/hari) } \\
\cline { 3 - 4 } & & $29-1-2002$ & $2-2-2007$ \\
\hline & Tanjung Priok & 147 & 168 \\
\hline & BMG Kemayoran & 104 & 235 \\
\hline & Cengkareng & 77 & 122 \\
\hline & Pakubuwono & 47 & 178 \\
\hline & Halim PK & 19 & 127 \\
\hline & Pasanr Minggu & - & 220 \\
\hline & Ciledug & 72 & 339,8 \\
\hline & Kedoya & 82 & 185 \\
\hline & Depok & 63 & 48 \\
\hline & Tambun & 61 & 201 \\
\hline & Citeko & 146 & 7,7 \\
\hline & Gunung Mas & 39 & 5 \\
\hline & Darmaga & 127 & 16 \\
\hline
\end{tabular}

Sumber: BMG, 2007 
Penyebaran curah hujan tersebut semakin jelas terlihat dari peta isohyet (Gambar 3). Dari peta isohyet terlihat bahwa pada tanggal 29 Januari 2002 terdapat dua pusat hujan yaitu di daerah Bekasi dan Depok hingga Bogor. Adanya curah hujan yang besar di Bekasi hingga ke arah Timur, seperti di Tambun menyebabkan banjir di daerah Bekasi hingga kawasan pesisir Pantai Utara wilayah Bekasi. Banyak kawasan permukinan dan lahan pertanian di sekitar Bekasi Utara hingga Tambun yang mengalami banjir. Sedangkan adanya pusat hujan di hulu Sungai Ciliwung yaitu di Depok hingga Bogor menyebabkan banjir di daerah Jakarta semakin besar. Sebab beberapa daerah sebelumnya telah terjadi banjir dan genangan air belum surut.

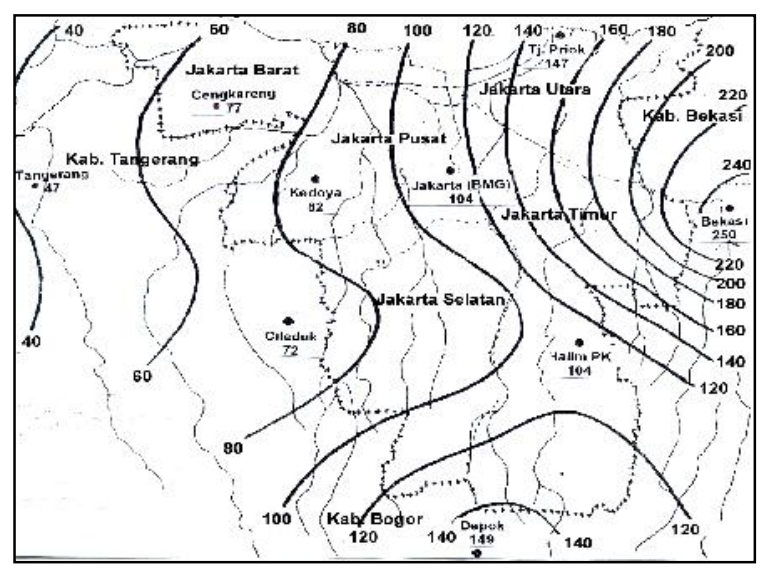

Gambar 3. Peta Isohyet Penyebaran Hujan Pada Tanggal 29 Januari 2002

Berdasarkan analisis frekuensi hujan dengan metode Gumbel untuk daerah Jakarta dan DAS Ciliwung, maka dapat disusun suatu hubungan antara curah hujan harian maksimum dengan periode ulangan, seperti yang disajikan pada Tabel 2 dan Gambar 4. Hasil analisis frekuensi hujan harian maksimum tersebut merupakan hasil kompilasi dari studi JICA dan Ditjen Pengairan (1997), dimana terdapat dua hasil analisis untuk curah hujan yaitu untuk daerah Jakarta dan DAS Ciliwung seluas 215 $\mathrm{km}^{2}$.

Tabel 2. Periode ulang curah hujan harian daerah Jakarta dan DAS Ciliwung

\begin{tabular}{|c|c|c|}
\hline $\begin{array}{c}\text { Periode } \\
\text { Ulang (thn) }\end{array}$ & $\begin{array}{c}\text { CH Jakarta } \\
(\mathrm{mm})\end{array}$ & $\begin{array}{c}\text { CH DAS Ciliwung } \\
\left(215 \mathrm{~km}^{2}\right)(\mathrm{mm})\end{array}$ \\
\hline 1000 & 315,2 & 185,6 \\
\hline 500 & 292,1 & 172,7 \\
\hline 250 & 269,1 & 159,7 \\
\hline 200 & 261,6 & 155,5 \\
\hline 100 & 238,5 & 142,5 \\
\hline 50 & 215,3 & 129,4 \\
\hline 30 & 198,1 & 119,8 \\
\hline
\end{tabular}

\begin{tabular}{|r|r|r|}
\hline 25 & 191,9 & 116,3 \\
\hline 20 & 184,3 & 112,0 \\
\hline 10 & 160,3 & 98,6 \\
\hline 5 & 135,4 & 84,5 \\
\hline 2 & 97,7 & 63,3 \\
\hline
\end{tabular}

Sumber : JICA dan Ditjen Pengairan, 1997

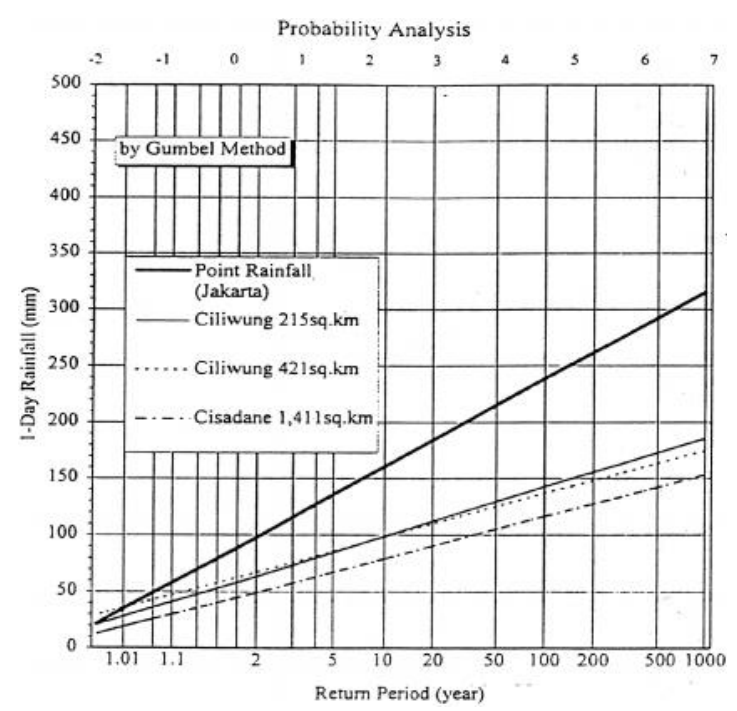

Gambar 4. Periode Ulang Curah Hujan Harian Daerah Jakarta Dan Sekitarnya

Dilihat dari akumulasi curah hujan sebelum kejadian, yaitu pada 29 Januari 2007 hingga 2 Februari 2007, maka curah hujan yang terjadi sangat besar. Akumulasi selama 5 hari di stasiun Ciledug mencapai 520,5 mm, di Cengkareng sekitar $354 \mathrm{~mm}$ dan di stasiun Halim Perdanakusumah $333 \mathrm{~mm}$. Tebal hujan yang demikian sangat ekstrim jika dibandingkan dengan pola normal hujan saat bulan Januari dan Februari. Berdasarkan hasil perhitungan rata-rata curah hujan tahun 1989 - 1999, curah hujan daerah Jakarta mempunyai puncak pada bulan Januari, kemudian pada bulan-bulan berikutnya curah hujan lebih rendah hingga September. Bulan Januari dan Februari merupakan bulan yang sangat tinggi curah hujannya yaitu $364 \mathrm{~mm}$ pada bulan Januari dan $329 \mathrm{~mm}$ pada bulan Februari (Gambar 5).

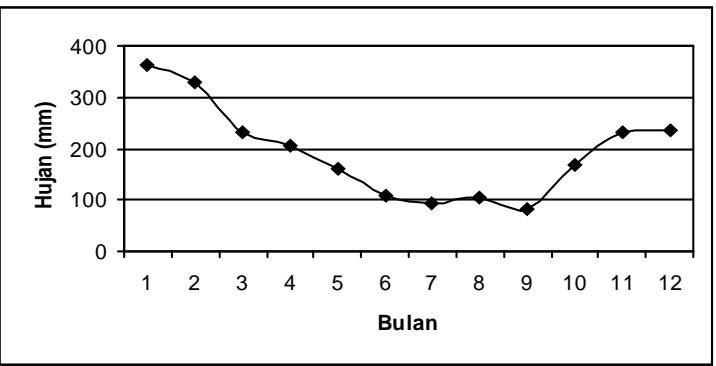

Gambar 5. Pola Curah Hujan Normal Daerah Jakarta Dan Sekitarnya 
Rata-rata curah hujan tersebut merupakan ratarata curah hujan dari 20 stasiun curah hujan, yaitu Cengkareng, BMG, Ciledug, Halim Perdana Kusumah, Cipete, Jelambar, Pakubuana, Bendungan Hilir, Rasela, Rawamangun, Bekasi, Depok, Pasar Ikan, Ciawi, Cibubur, Tanjung Priok, Tangerang, Menteng, Pondokgede, dan Serpong.

Untuk hasil analisis frekuensi curah hujan tersebut maka curah hujan yang terjadi pada tanggal 2 Februari 2007 untuk daerah Jakarta dan sekitarnya merupakan curah hujan dengan periode ulang (T) 1 hingga 1000. beberapa curah hujan dengan periode ulang yang besar antara lain: Cileduk (339,8 $\mathrm{mm}=1000$ tahun), Kemayoran 98 tahun dan Pasar Minggu 50 tahun. Jika dibandingkan dengan kejadian banjir pada 29 Januari 2002 di daerah Jakarta dan sekitarnya merupakan curah hujan dengan periode ulang (T) 1 hingga 150 tahun. Apabila dibandingkan untuk setiap stasiun maka hujan yang terjadi di Tanjung Priok (147 mm) mempunyai periode ulang 7 tahun. Selanjutnya berturut-turut stasiun BMG (82 mm) mempunyai $\mathrm{T}$ sebesar 2 tahun, Halim Perdana Kusumah (104 mm) mempunyai $\mathrm{T}$ sebesar 2,2 tahun, Depok (149 mm) mempunyai $T$ sebesar 8,2 tahun, Citeko Bogor (146 mm) mempunyai T sebesar 7,9 tahun, dan Bekasi $(250 \mathrm{~mm})$ mempunyai T sebesar 150 tahun.

Sementara itu untuk rata-rata curah hujan DAS Ciliwung yang mencapai $142,5 \mathrm{~mm} /$ hari pada 2 Februari 2007. Curah hujan demikian mempunyai periode ulang sekitar 100 tahun. Hal ini lebih besar jika dibandingkan dengan rata-rata hujan periode 29 Januari 2002 yaitu $110 \mathrm{~mm} /$ hari yang mempunyai periode ulang 20 tahun.

Periode ulang (return period) adalah periode waktu rata-rata yang diharapkan terjadi antara dua kejadian yang berurutan (Chow et.al., 1988). Hal ini seringkali disalahartikan sebagai sesuatu yang secara statistik dibenarkan bahwa dalam hal (misalnya peristiwa banjir) akan terjadi secara berurutan dengan waktu yang tetap. Dengan demikian maka stasiun hujan dengan $\mathrm{T}$ sebesar 150 tahun artinya identik dengan pengertian bahwa setiap tahun, kemungkinan terjadinya curah hujan yang sama atau lebih besar dari $250 \mathrm{~mm} /$ hari adalah sebesar 0,4 \%. Demikian pula halnya dengan periode ulang 7 tahunan sebesar $147 \mathrm{~mm} /$ hari adalah identik dengan pengertian bahwa setiap tahun, kemungkinan terjadinya curah hujan yang sama atau lebih besar dari $147 \mathrm{~mm} /$ hari adalah sebesar $14,3 \%$.

Dengan curah hujan yang demikian besar tersebut, maka banjir terjadi secara merata di daerah Jakarta dan sekitarnya. Hampir seluruh sungai yang ada di Jakarta mempunyai tinggi muka air yang melebihi dari tinggi muka air normal. Sungai yang ada tidak mampu menampung dan mengatuskan aliran permukaan tersebut ke laut sehingga terjadi luapan di sepanjang sungai. Hal ini terlihat dari tinggi muka air dari sungai Ciliwung di Katulampa tercatat $250 \mathrm{~cm}$, melebihi tinggi normal $170 \mathrm{~cm}$. Adanya pasokan aliran permukaan dari wilayah tengah DAS Ciliwung dan sekitarnya menyebabkan tinggi muka air di Depok mencapai $465 \mathrm{~cm}$. Di bagian hilir yaitu di Pintu Air Manggarai mencapai $1.090 \mathrm{~cm}$ melebihi tinggi normal $170 \mathrm{~cm}$. Akibatnya melimpas di sekitar Manggarai dan Bukit Duri. Demikian pula halnya dengan sungaisungai yang lainnya, tinggi muka air melebih batas normal (Tabel 2).

Tabel 2. Tinggi Muka Air Beberapa Sungai Saat Banjir Besar Di Jakarta Pada Februari 2007

\begin{tabular}{|l|c|c|c|c|}
\hline \multicolumn{1}{|c|}{ Lokasi } & $\begin{array}{c}\text { Tinggi } \\
\text { Normal }\end{array}$ & Tanggal & Waktu & $\begin{array}{c}\text { Tinggi } \\
\text { Muka } \\
\text { Air }\end{array}$ \\
\hline Katulampa & 170 & $3 / 2 / 07$ & 11.00 & 250 \\
\hline Depok & 200 & $3 / 2 / 07$ & 16.00 & 465 \\
\hline $\begin{array}{l}\text { Pintu Air } \\
\text { Manggarai }\end{array}$ & 750 & $4 / 2 / 07$ & 08.00 & 1090 \\
\hline $\begin{array}{l}\text { Pintu Air } \\
\text { Karet }\end{array}$ & 450 & $4 / 2 / 07$ & 11.00 & 770 \\
\hline Sunter Hulu & 140 & $3 / 2 / 07$ & $\begin{array}{c}12.00- \\
14.00\end{array}$ & 260 \\
\hline $\begin{array}{l}\text { Cipinang } \\
\text { Hulu }\end{array}$ & 150 & $3 / 2 / 07$ & 10.00 & 210 \\
\hline $\begin{array}{l}\text { Pintu Air } \\
\text { Pulogadung }\end{array}$ & 550 & $3-$ & $07.00-$ & 785 \\
\hline
\end{tabular}

\section{KESIMPULAN}

Banjir yang terjadi pada tanggal 2 Februari 2007 disebabkan adanya curah hujan yang tinggi. Adanya daerah dengan tekanan udara rendah di Australia bagian utara dan adanya daerah pertemuan angin (ITCZ) pada posisi di sekitar laut Jawa hingga Laut Banda; menyebabkan massa uap air yang basah yang berasal dari Asia berkumpul di tempat tersebut.

Berdasarkan hasil analisis frekuensi curah hujan tersebut maka curah hujan yang terjadi pada tanggal 2 Februari 2007 untuk daerah Jakarta dan sekitarnya merupakan curah hujan dengan periode ulang (T) 1 hingga 1000 . beberapa curah hujan dengan periode ulang yang besar antara lain: Cileduk $(339,8 \mathrm{~mm}=$ 1000 tahun), Kemayoran 98 tahun dan Pasar Minggu 50 tahun.

Sementara itu untuk rata-rata curah hujan DAS Ciliwung yang mencapai $142,5 \mathrm{~mm} /$ hari pada 2 Februari 2007. Curah hujan demikian mempunyai periode ulang sekitar 100 tahun. Hal ini lebih besar jika dibandingkan dengan rata-rata hujan periode 29 Januari 2002 yaitu $110 \mathrm{~mm} /$ hari yang mempunyai periode ulang 20 tahun. 
Dengan curah hujan tersebut menyebabkan kemampuan saluran drainase dan pengendali banjir tidak mampu mengatuskan atau mengalirkan limpasan permukaan sehingga terjadi banjir.

\section{DAFTAR PUSTAKA}

1. Bappenas, 2007. Laporan Perkiraan Kerusakan dan Kerugian Pasca Banjir Awal Februari 2007 di Wilayah Jabodetabek (Jakarta, Bogor, Depok, Tangerang dan Bekasi). Jakarta.

2. Chow, V.T., D.R. Maidment, and L.W. Mays. 1988. "Applied Hydrology". McGraw Hill Book Company. New York.

3. FAO \& CIFOR. 2005. Forests and Floods. Drowning in Fiction or Thriving on Facts? RAP Publication 2005/3. Forest Perspectives 2. Bangkok

4. Gupta, A., 2003. Flood and Floodplain Management in North East India ; An Ecological Perspective. Proceedings of the 1st International Conference on Hyadrology nd Water Resources in Asia Pacific Region (APHW 2003). Kyoto.
5. Japan International Cooperation Agency (JICA) and Directorate General of Water Resources Development, 1997, "The Study on Comprehensive River Water Management Plan in Jabotabek". Final Report Volume IV Annexes I, Jakarta.

6. Parry, M.L., Blantrain de Rozari, M., Chong, A.L. and Panich, S. 1992. The Potential Socio-Economic Effect of Climate Change in South East Asia. Nairobi : United Nations Environment Programme.

7. Speer, M.S. and Leslie, L.M. 2000. A Comparison of Five Flood Rain Events Over The New South Wales North Coast and A Case Study. International Journal of Climatology. Int. J. Climtol. 20: 543-563.

8. Subarkah, I., 1980. "Hidrologi Untuk Perencanaan Bangunan Air". Penerbit Idea Dharma, Bandung

9. United Nations International Strategy for Disaster Reduction, 2003 Living with Risk. Turning the Tide on Disasters Toward Sustainable Development. Geneva.

10. World Meteorological Organization, 2004. Water and Disasters. Be Informed and $\mathrm{Be}$ Prepared. WMO No. 971. Geneva. 